\title{
Leaf waxes from aeolianite-paleosol sequences on Fuerteventura and their potential for paleoenvironmental and climate reconstructions in the arid subtropics
}

\author{
Julian Struck ${ }^{1, a}$, Christopher B. Roettig ${ }^{2}$, Dominik Faust ${ }^{3}$, and Roland Zech ${ }^{1, a}$ \\ ${ }^{1}$ Institute of Geography and Oeschger Centre for Climate Change Research, \\ University of Bern, Bern, Switzerland \\ ${ }^{2}$ Landscape Ecology, Dresden University of Technology, Dresden, Germany \\ ${ }^{3}$ Physical Geography, Dresden University of Technology, Dresden, Germany \\ anow at: Physical Geography, Friedrich-Schiller University, Jena, Germany
}

Correspondence: Julian Struck (julian.struck@uni-jena.de)

Relevant dates: $\quad$ Published: 4 January 2018

How to cite:

Struck, J., Roettig, C. B., Faust, D., and Zech, R.: Leaf waxes from aeolianite-paleosol sequences on Fuerteventura and their potential for paleoenvironmental and climate reconstructions in the arid subtropics, E\&G Quaternary Sci. J., 66, 109-114, https://doi.org/10.5194/egqsj-66-109-2018, 2018., E\&G Quaternary Sci. J., 66, 109-114, https://doi.org/10.5194/egqsj-66-109-2018, 2018.

\section{Introduction}

One of the biggest challenges for our civilization is climate change. Especially regions that are characterized by harsh conditions today will be affected by major changes in the future. It is therefore essential to investigate and understand anthropogenic effects and natural climate variability in the past, and attention should be paid particularly to arid and semiarid regions, which may suffer from further aridization.

Fuerteventura is such a region, yet little is known about past climate and environmental conditions. Paleoenvironmental reconstructions on Fuerteventura are mainly based on morphodynamic and stratigraphical investigations of aeolianite-paleosol sequences (Faust et al., 2015; Roettig et al., 2017, and references therein).

Lipid biomarkers, especially $n$-alkanes, may serve as a powerful, novel tool for paleoenvironmental reconstruction. Long-chain $n$-alkanes are epicuticular leaf waxes, which protect the plant from various environmental influences (Castañeda et al., 2016). They can provide numerous environmental information. The chain length patterns, for example, can reflect the dominant vegetation type (Zech et al., 2009, 2013;
Schäfer et al., 2016b). Moreover, the hydrogen isotopic composition of $n$-alkanes may serve as proxy for paleohydrological conditions, recording changes in precipitation, evapotranspiration and temperature (Sachse et al., 2012; Zech et al., 2013). Furthermore, recent technological developments allow compound-specific ${ }^{14} \mathrm{C}$ dating by accelerated mass spectroscopy to establish more robust chronologies (Häggi et al., 2014; Haas et al., 2017).

For this study $n$-alkane analyses were applied for two aeolianite-paleosol sequences on Fuerteventura to test their potential for paleoenvironmental reconstructions under arid conditions in general and the $n$-alkanes preservation in a sparsely vegetated landscape in particular.

\section{Geographical setting}

The northern tip of Fuerteventura is mainly characterized by Tertiary and Pleistocene volcanism. Within the volcanic fields, composed of lava and pyroclastics, several fields of dunes and sand sheets developed during the Pleistocene and Holocene (Fig. 1) (Roettig et al., 2017). In the interior of the 


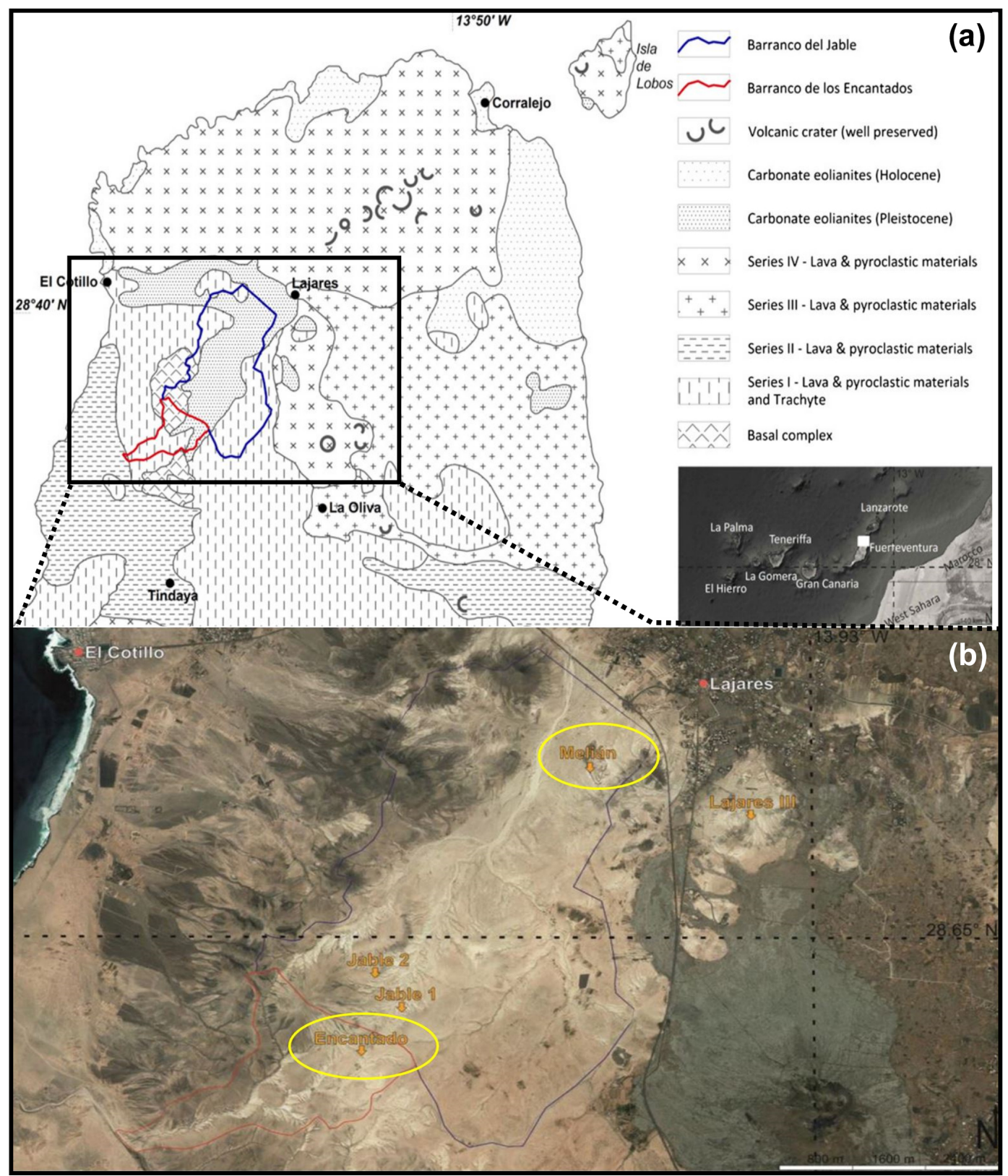

Figure 1. Location map and the northern tip of Fuerteventura showing major geological units and both catchments of the study area (a). Google Earth image of the catchments Barranco del Jable (blue) and Barranco de los Encantados (red). Aeolianite-paleosol sequences are marked in yellow (b) (modified after Roettig et al., 2017).

islands up to $13 \mathrm{~m}$ thick successions of alternating sand layers and paleosols are perfect archives to reflect past climate changes as well as geological and morphological processes shaping this landscape. The sediments are mainly composed of biogenetic coarse sands of shelf origin (dune sands), partly mixed with volcanic material and dust from the Sahara.

Nowadays, deeply incised gully systems allow the recognition of different paleosurfaces which document periods of soil-forming processes and prevailing dust imprint. The study area can be separated into two catchments: the Bar- ranco de los Encantados and the Barranco del Jable (Fig. 1). Both are characterized by arid conditions (like the whole island), sparse vegetation cover and active morphodynamics in the form of huge gully systems (Faust et al., 2015; Roettig et al., 2017).

Five aeolianite-paleosol sequences have previously been investigated for sediment composition, sedimentation, soil formation and geochemical features (Faust et al., 2015; Roettig et al., 2017). Based on these investigations and 16 infrared stimulated luminescence ages, Roettig et al. (2017) 
correlated all five sequences and established a preliminary chronology.

From two of these aeolianite-paleosol sequences, we selected a total of 15 samples (Encantado: 7; Melián: 8) for leaf wax $n$-alkane analyses. Samples from Encantado cover the time back to $280 \mathrm{ka}$, while samples from Melián go back to $140 \mathrm{ka}$.

\section{Methods}

Dry, homogenized bulk sediments $(\sim 35 \mathrm{~g},<2 \mathrm{~mm})$ were extracted using an accelerating solvent extractor $(6.9 \mathrm{MPa}$, $100^{\circ} \mathrm{C}$; Dionex 200) with a dichloromethane/methanol ratio of $9: 1$. The total lipid extracts were separated into aliphatic, polar and acidic fractions over aminopropyl silica gel $(45 \mathrm{~mm}$; Supelco) pipette columns. The aliphatics (including $n$-alkanes) were eluted with hexane and spiked with $5 \mathrm{a}$-androstanone as an internal standard. The $n$-alkane concentrations were quantified by a gas chromatography-flame ionization detector (GC-FID) relative to the internal standard and two external standards $\left(n-\mathrm{C}_{20}\right.$ to $n-\mathrm{C}_{40}$ alkane mixture; Supelco: 40, $4 \mathrm{ng}$ ). After quantification, all samples were additionally cleaned over coupled zeolite-silver nitrate pipette columns, and the measuring procedure on the GC-FID was repeated.

Total $n$-alkane concentration was calculated as the sum of $n-\mathrm{C}_{25}$ to $n-\mathrm{C}_{35}$. The average chain length (ACL) was determined by the following equation:

$\mathrm{ACL}=\frac{\left(27 \times n-\mathrm{C}_{27}+29 \times n-\mathrm{C}_{29}+31 \times n-\mathrm{C}_{31}+33 \times n-\mathrm{C}_{33}\right)}{\left(n-\mathrm{C}_{27}+n-\mathrm{C}_{29}+n-\mathrm{C}_{31}+n-\mathrm{C}_{33}\right)}$.

The ACL indicates chain length variations of $n$-alkanes and can be used as proxy for vegetation changes. Longer chain lengths, typically $n$ - $\mathrm{C}_{31}$ and $n$ - $\mathrm{C}_{33}$, indicate a dominance of grasses and herbs, whereas shorter chain lengths $\left(n-\mathrm{C}_{27}\right.$ and $n-\mathrm{C}_{29}$ ) mainly derive from shrubs and deciduous trees (Zech et al., 2009, 2013; Schäfer et al., 2016b). The odd-over-even predominance (OEP) of the $n$-alkanes is a proxy for degradation of the $n$-alkanes:

$\mathrm{OEP}=\frac{\left(n-\mathrm{C}_{27}+n-\mathrm{C}_{29}+n-\mathrm{C}_{31}+n-\mathrm{C}_{33}\right)}{\left(n-\mathrm{C}_{26}+n-\mathrm{C}_{28}+n-\mathrm{C}_{30}+n-\mathrm{C}_{32}\right)}$.

High OEP values are typical for fresh plant material, whereas lower OEPs $(<5)$ indicate enhanced degradation (Zech et al., 2009; Schäfer et al., 2016b).

\section{Results}

Total $n$-alkane concentrations for the aeolianite-paleosol sequence Encantado are low, ranging from 0.22 to $0.52 \mu \mathrm{g} \mathrm{g}^{-1}$ (Fig. 2). The OEPs are also very low, with values not even exceeding 2.1. The ACL ranges from 29.9 to 30.4.

Five samples from Melián also have low $n$-alkane concentrations between 0.38 and $0.58 \mu \mathrm{gg}^{-1}$ (Fig. 2). The other three samples have higher concentrations up to $2.16 \mu \mathrm{g} \mathrm{g}^{-1}$. The OEP follows the same down profile trend. Samples with a low concentration show also low OEPs, whereas the higher concentrated samples have OEPs above 5, indicating good preservation. The ACL ranges from 29.8 to 31.6 and has the same pattern as the concentration and OEP.

\section{Discussion}

As might be expected, $n$-alkane concentrations for the aeolianite-paleosol sequences on Fuerteventura remain on a relatively low level. In this respect, our study area in the arid subtropics, such as the loess-paleosol sequence (LPS) El Paraiso in central Spain, which ranges from 0.04 to $\sim 0.5 \mu \mathrm{g} \mathrm{g}^{-1}$ for the last glacial period (Schäfer et al., 2016a). Much higher concentrations are found in more humid areas such as the LPS Crvenka (Carpathian Basin) with concentrations of up to $4.5 \mu \mathrm{g} \mathrm{g}^{-1}$ (Zech et al., 2013). Most probably, the combination of little wax production (sparse vegetation) and poor preservation, as indicated by the low OEPs, is responsible for the low concentrations in the sandy sequences on Fuerteventura. OEPs in the LPS El Paraiso and LPS Crvenka, for example, are mostly $>5$, indicating much better preservation (Schäfer et al., 2016a; Zech et al., 2013).

Given the poor preservation of the $n$-alkanes at Encantado and Melián, it cannot be ruled out that chain length variations, as indicated by the ACL, are effected by degradation. Indeed, the ACL closely follows the down-profile patterns of the OEP, and the chain length variations may be more artifacts related to degradation rather than a record of paleovegetation. This would mean that paleoenvironmental reconstructions in terms of paleovegetation is hardly possible. In order to further investigate this issue, we plotted all samples in an endmember model (Fig. 3). Endmember models combine the OEP (i.e., degradation) versus $n$-alkane ratios (i.e., chain length as proxy for the vegetation type). Plants and topsoil samples typically plot along so-called degradation lines, and several calibration studies in Europe have confirmed the notion that longer chains $\left(n-\mathrm{C}_{31}\right.$ and $\left.n-\mathrm{C}_{33}\right)$ indicate input from grasses and herbs, whereas shorter chains $\left(n-\mathrm{C}_{27}\right.$ and $n-\mathrm{C}_{29}$ ) indicate input from deciduous trees and shrubs (Zech et al., 2013; Schäfer et al., 2016b). Additionally, however, the endmember plots and the degradation lines illustrate the challenge to interpret samples with low OEP values. With decreasing OEP, both degradation lines converge, and an interpretation in terms of vegetation type is no longer possible. In the case of Encantado and Melián, all samples from Encantado and most samples from Melián plot very far left; i.e., they are strongly degraded and an attribution of these samples to a vegetation type is no longer reliable (Fig. 3).

Only three samples from Melián are sufficiently well preserved. These three samples are the ones characterized by higher $n$-alkane concentrations $\left(>1.5 \mu \mathrm{g} \mathrm{g}^{-1}\right)$ and ACLs above 30.8 . Their chain length patterns can be interpreted to 


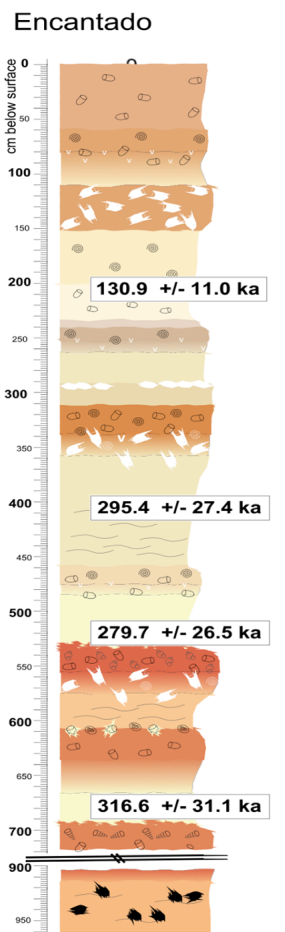

Melián (composite)

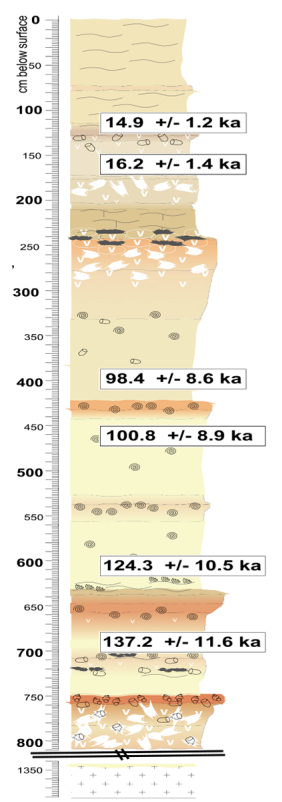

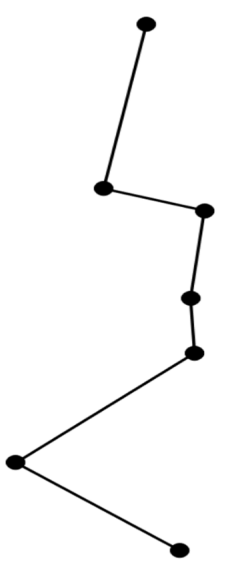

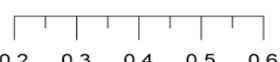

Total $n$-alkane conc. [ $\mu \mathrm{g} \mathrm{g}^{-1}$ ]
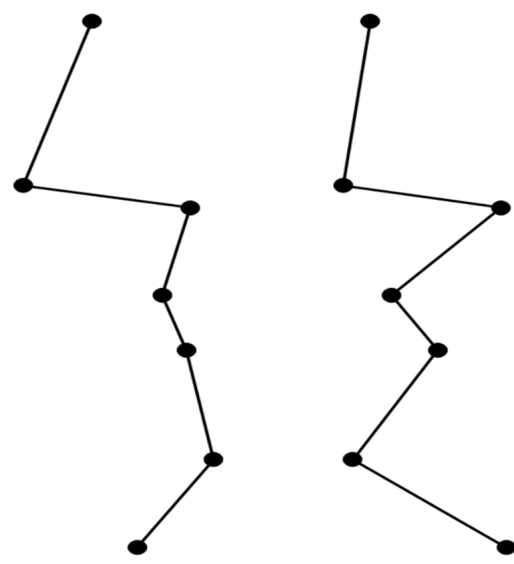

(a)

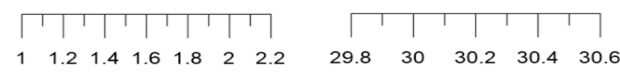

OEP

ACL

(b)
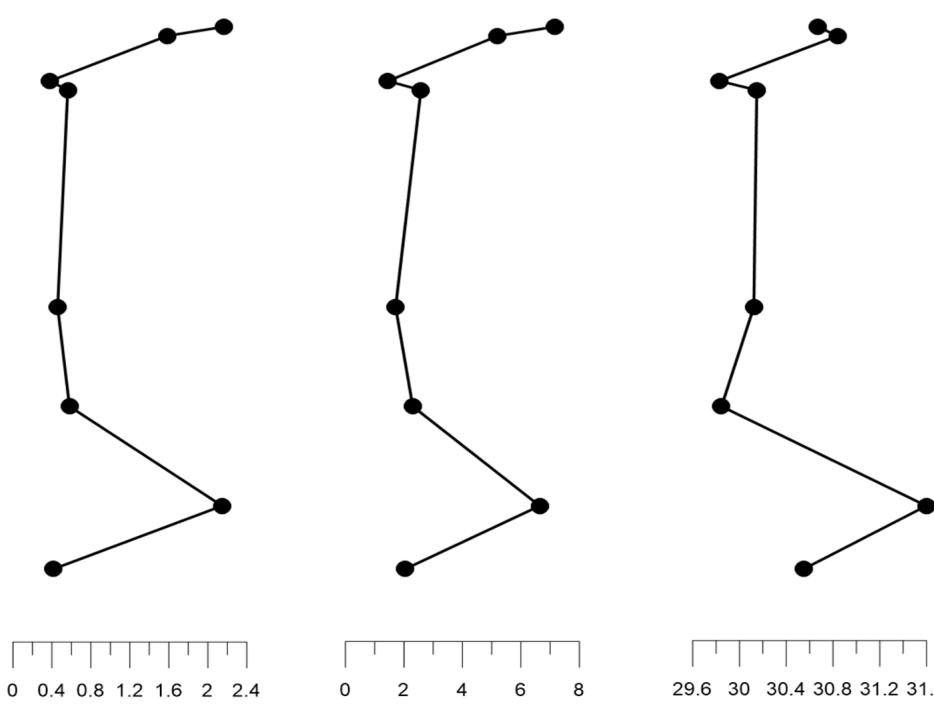

Total $n$-alkane conc. [ $\mu \mathrm{g} \mathrm{g}^{-1}$ ]
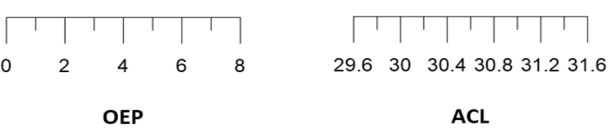

$\mathrm{ACL}$

Coated \& translocated molluscs

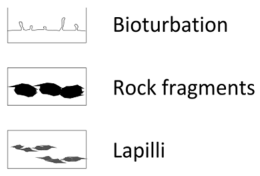

Pomatias lanzarotensis

Maximum of

Cochlicella sp.

Recalcification features (patchy/dispers)

Crust of calcium carbonate / Caliche

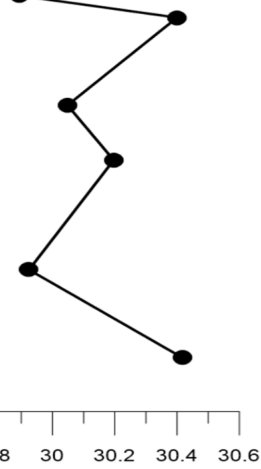

Brood cells $-\mathrm{CaCO}_{3}$ coated

B. Brood cells - translocated

(2) Molluscs

Molluscs \& broken pieces of molluscs

Figure 2. $n$-Alkane results for the aeolianite-paleosol sequence Encantado (a) and Melián (b). Detailed stratigraphic interpretation can be found in Roettig et al. (2017). Profile sketches are modified after Roettig et al. (2017). 


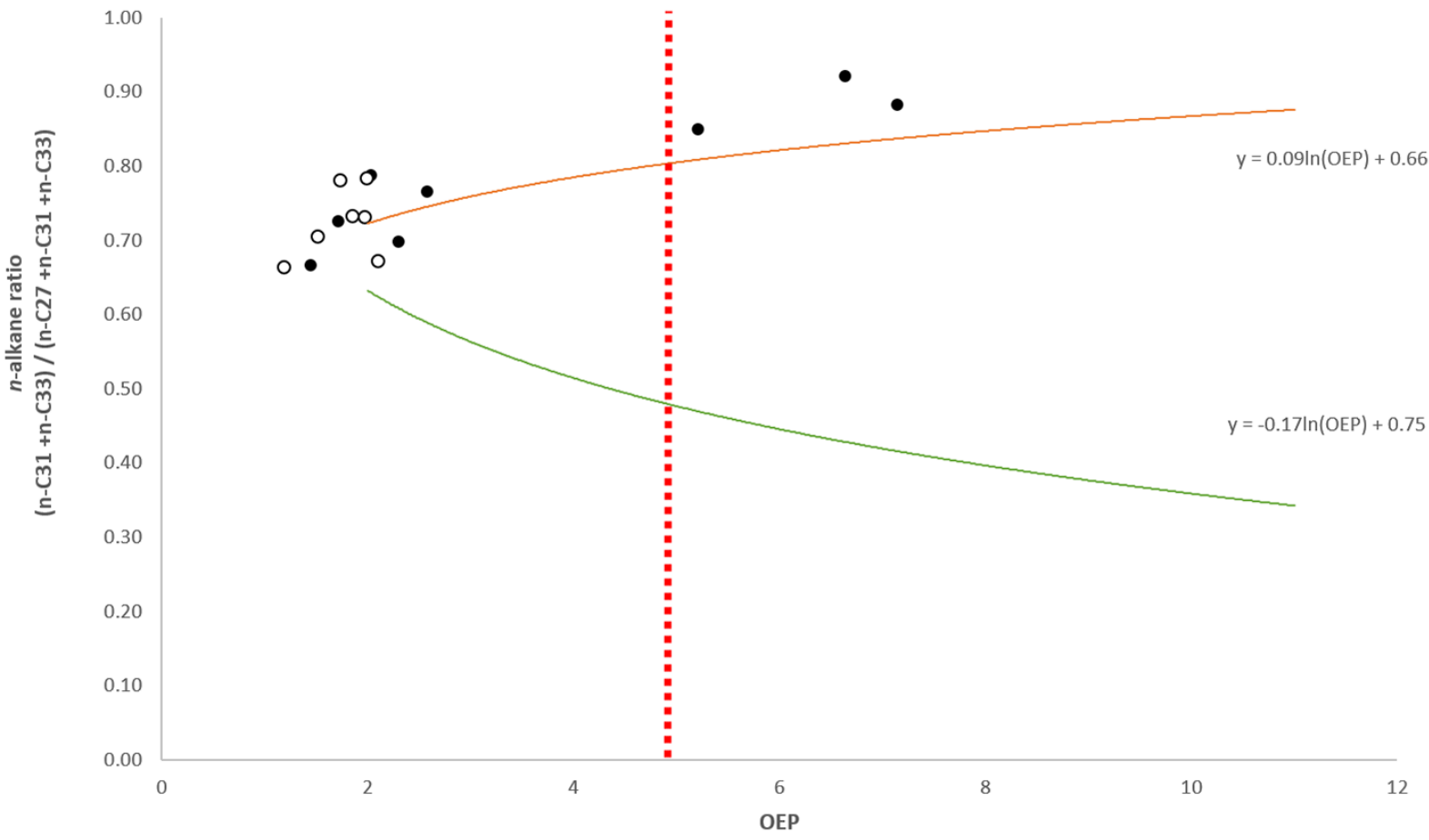

Figure 3. Endmember model for the samples from Encantado (white) and Melián (black). The dotted red line separates samples with good preservation $(\mathrm{OEP}>5)$ and strongly degraded samples $(\mathrm{OEP}<5)$. The orange line represents the degradation line for grasses and herbs, the green line the degradation line for deciduous trees and shrubs (after Schäfer et al., 2016b).

indicate a dominant leaf wax input from grasses and herbs, which were thus likely the dominant type of vegetation $\sim 15$ and $\sim 130$ ka (Fig. 2).

\section{Conclusions}

$n$-Alkane concentrations are relatively low in the two investigated aeolianite-paleosol sequences Encantado and Melián, most likely due to low leaf wax production (sparse vegetation) and poor preservation. Apart from three samples, OEP values are below 5 , indicating strong degradation. This prevents a robust interpretation of the chain length patterns, and only the three sufficiently preserved samples can be interpreted in terms of paleovegetation, documenting dominant input from grasses and herbs at $\sim 15$ and $130 \mathrm{ka}$. It must be considered that an interpretation in terms of long-chain vs. short-chain $n$-alkanes is based on previous studies (e.g., Zech et al., 2013, and Schäfer et al., 2016a, b). For Fuerteventura, recent plant material has not been measured yet and would be necessary for further interpretations.

Even though concentrations are low and preservation is poor, there is potential for compound-specific deuterium isotope measurements and paleohydrological reconstruction because the lipid extracts from most samples contained sufficient amounts of possible target compounds $(\sim 1 \mu \mathrm{g}$ for $n$ $\mathrm{C}_{31}$ ). Concentrations are also high enough in most samples for compound-specific ${ }^{14} \mathrm{C}$ measurements $(\sim 20 \mu \mathrm{g}$ total $n$ - alkane concentration), which could help to establish robust chronologies for the sequences back to $\sim 30 \mathrm{ka}$.

Data availability. Underlying $n$-alkane results can be found in the Supplement.

\section{The Supplement related to this article is available online at https://doi.org/10.5194/egqsj-66-109-2018-supplement.}

Competing interests. The authors declare that they have no conflict of interest.

Acknowledgements. We thank the Swiss National Science Foundation (SNF) and the German Research Foundation (DFG) for funding (SNF: 150590; DFG: FA 239/18-1) and Daniel Wolf for discussion.

\section{References}

Castañeda, I. S., Thibaut, C., Dupont, L., Jung-Hyun, K., Malaizé, B., and Schouten, S.: Middle to Late Pleis- 
tocene vegetation and climate change in subtropical southern East Africa, Earth Planet. Sc. Lett., 450, 306-316, https://doi.org/10.1016/j.eps1.2016.06.049, 2016.

Faust, D., Yanes, Y., Willkommen, T., Roettig, C., Richter, D., Richter, D., v. Suchodoletz, H., and Zöller, L.: A contribution to the understanding of late Pleistocene dune sand-paleosolsequences in Fuerteventura (Canary Islands), Geomorphology, 246, 290-304, https://doi.org/10.1016/j.geomorph.2015.06.023, 2015.

Haas, M., Bliedtner, M., Borodynkin, I., Salazar, G., Szidat, S., Eglinton, T. I., and Zech, R.: Radiocarbon Dating of Leaf Waxes in the Loess-Paleosol Sequence Kurtak, Central Siberia, Radiocarbon, 59, 165-176, https://doi.org/10.1017/RDC.2017.1, 2017.

Häggi, C., Zech, R., McIntyre, C., Zech, M., and Eglinton, T. I.: On the stratigraphic integrity of leaf-wax biomarkers in loess paleosols, Biogeosciences, 11, 2455-2463, https://doi.org/10.5194/bg-11-2455-2014, 2014.

Roettig, C.-B., Kolb, T., Wolf, D., Baumgart, P., Richter, C., Schleicher, A., Zöller, L., and Faust, D.: Complexity of Quaternary aeolian dynamics (Canary Islands), Palaeogeogr. Palaeocl., 472, 146-162, https://doi.org/10.1016/j.palaeo.2017.01.039, 2017.

Sachse, D., Billault, I., Bowen, G. J., Chikaraishi, Y., Dawson, T. E., Feakins, S. J., Freeman, K. H., Magill, C. R., McInerney, F. A., van der Meer, M. T. J., Polissar, P., Robins, R. J., Sachs, J. P., Schmidt, H.-L., Sessions, A. L., White, J. W. C., West, J. B., and Kahmen, A.: Molecular Paleohydrology: Interpreting the Hydrogen-Isotopic Composition of Lipid Biomarkers from Photosynthesizing Organisms, Annu. Rev. Earth Pl. Sc., 40, 221-249, https://doi.org/10.1146/annurev-earth-042711$105535,2012$.
Schäfer, I. K., Bliedtner, M., Wolf, D., Faust, D., and Zech, R.: Evidence for humid conditions during the last glacial from leaf wax patterns in the loess-paleosol sequence El Paraíso, Central Spain, Quatern. Int., 407, 64-73, https://doi.org/10.1016/j.quaint.2016.01.061, 2016a.

Schäfer, I. K., Lanny, V., Franke, J., Eglinton, T. I., Zech, M., Vysloužilová, B., and Zech, R.: Leaf waxes in litter and topsoils along a European transect, SOIL, 2, 551-564, https://doi.org/10.5194/soil-2-551-2016, 2016 b.

Zech, M., Buggle, B., Leiber, K., Marković, S., Glaser, B., Hambach, U., Huwe, B., Stevens, T., Sümegi, P., Wiesenberg, G., and Zöller, L.: Reconstructing Quaternary vegetation history in the Carpathian Basin, SE Europe, using $n$-alkane biomarkers as molecular fossils. Problems and possible solutions, potential and limitations, E\&G Quaternary Sci. J., 58, 148-155, https://doi.org/10.3285/eg.58.2.03, 2009.

Zech, R., Zech, M., Marković, S., Hambach, U., and Huang, Y.: Humid glacials, arid interglacials? Critical thoughts on pedogenesis and paleoclimate based on multiproxy analyses of the loess-paleosol sequence Crvenka, Northern Serbia, Palaeogeogr. Palaeocl., 387, 165-175, https://doi.org/10.1016/j.palaeo.2013.07.023, 2013. 